\title{
CYBERBULLIED TO DEATH: AN ANALYSIS OF VICTIMS TAKEN FROM RECENT EVENTS
}

\author{
William Stanley Pendergrass, American Public University System, william.pendergrass@mycampus.apus.edu \\ Michelle Wright, Masaryk University, michelle.wright@mail.muni.cz
}

\begin{abstract}
In this paper, we analyze information collected from a variety of electronic news sources on cases of cyberbullying. Utilizing a case study approach, we examined in detail victims' experiences with cyberbullying. Each case study involved a female teenage girl who committed suicide following repeated cyberbullying. Two of the three cases involved the sharing of explicit sexual material, which triggered further cyberbullying behaviors by the girls' classmates. All girls had tried to escape the cyberbullying behaviors by leaving school and/or switching schools, but they were intentionally and continuously targeted. In addition, the girls had prior suicide attempts before they committed suicide. We argue that parents should be aware of what their kids are doing online and establish rules for technology usage, and encourage their children to talk to them immediately if they are cyberbullied.
\end{abstract}

Keywords: Cyberbullying, bullying, suicide, victim, Anonymous

\section{INTRODUCTION}

The story has seemingly become all too familiar these days. A young person, usually but not always, a teenage girl, inexplicably takes her own life. Her family, friends and teachers are shocked, shaken and left wondering, "Why did she do this?" Then slowly a picture emerges of a person being tormented over time, driven to the point of wanting to end the pain that she cannot escape from. As it turns out, the electronic devices her parents provided for her to keep in touch, do her homework, and socialize with her friends, turned into devices which provided a constant barrage of hate, insults, and abuse. Cyber bullying cases seem to be increasing. As cell phones turned into smart phones, as school ground fights turned into Facebook assaults, the abusers now have a method to reach their victims 24 hours a day. What can we learn from the victims? What can we learn from the perpetrators? What can be done to help prevent this type of abuse? This study will examine several recent cyber bullying cases from the perspectives of the victims in order to come up with themes as to how to help stop this type of torment.

\section{What is Cyberbullying?}

Olweus [14] introduced the definition of bullying, which is currently being used. In order for an act to be considered bullying, the act must be intentional, be based on an imbalance of power and repeated [9, 14]. Intentionality is differentiated from random or accidental actions which could harm someone. An imbalance of power represents the differences between victims and perpetrators in regard to perpetrators' strength, position, intelligence or popularity. Finally, repetition means that the harmful intentional actions reoccur over a period of time [9].

Cyberbullying is bullying, using the above definition, but it involves "information and communication technologies (ICTs) or other types of Internet technologies" [9]. Many children often are provided cell phones or smart phone so that their parents can keep in touch with them. These electronic devices have become the electronic means of conversation and social standing in the children's world. Services such as texting as well as applications such as Facebook, Twitter, Instagram and Vine allow for the free flow of communication among today's youth. In addition to those services, conversation applications such as ask.fm, Kik and Voxer allow for users to post anonymously or through a username, often creating a perfect avenue for cyberbullies [1]. In cyberbullying experiences, the identity of the bully may or may not be known. The recent proliferation of smart phone apps can often leave parents clueless to their children's true online presence.

[C]yberbullying experts said cellphone messaging applications are proliferating so quickly that it is increasingly difficult for parents to keep pace with their children's complex digital lives. "It's a whole new culture, and the thing is that as adults, we don't know anything about it because it's changing every single 


\section{Issues in Information Systems \\ Volume 15, Issue I, pp. 132-140, 2014}

day," said Denise Marzullo, the chief executive of Mental Health America of Northeast Florida in Jacksonville, who works with the schools there on bullying issues. No sooner has a parent deciphered Facebook or Twitter or Instagram than his or her children have migrated to the latest frontier. "It's all of these small ones where all this is happening," Ms. Marzullo said. [1]

Cyberbullying can occur through electronically-mediated communication at school; however cyberbullying behaviors commonly occur outside of school as well" [25]. Cyberbullying also is dependent on the social group affected. What behaviors an adult might consider cyberbullying, some teenagers might see it only as "Drama" [2]. Drama is "social and interpersonal; involves relational conflict; reciprocal; gendered; and, often performed for, in, and magnified by networked publics" [10]. Teenagers between the ages of 12 to 14 appear to be the most vulnerable to cyberbullying victimization [25]. This coincides with the ages of those vulnerable to offline bullying. Cyberbullying is more prevalent in middle school than high school and is most likely to occur when starting middle school or starting at a new school $[5,15]$.

Cyberbullying also increases the risk of suicide in young victims. In a recent Dutch meta-analysis of 34 studies of 284,375 people that focused on the effects of bullying and suicidal thoughts along with an analysis of 9 studies of 70,102 people that focused on the relationship between bully victims and suicide attempts aged between 9 and 21 years of age, the researchers found that those who are bullied were more than twice as likely to have suicidal thoughts as those who had not been bullied. Additionally, bullying victims were two and a half times more likely to attempt to commit suicide [21].

\section{The Profiles of Cyber Victims}

Victims of cyberbullying generally report that they feel more dependent on the Internet, and take more Internetrelated risks (e.g., meeting online strangers offline) [26]. Many cyber victims experience peer rejection, do not get along with their peers, and have problems concerning emotional closeness with their parents [7, 29]. They are also likely to engage in unusual behaviors (e.g., twitching), daydreaming, and impulsivity. There are many offline consequences of cyberbullying. For instance, cyberbullying victimization relates to offline problem behaviors, such as drinking liquor, skipping school without an excuse, and cheating on a test [6]. In addition, victims also experience anxiety, depression, and negative self-image [7, 19]. Cyber victims also fear for their safety at school, and have academic achievement problems [30]. With a working definition, an understanding of what does not constitute cyberbullying, and an idea of the general social groups as well as an overview of the characteristics and psychological profiles of victims, we can examine some recent case studies of cyberbullying in an effort to trace victims' specific experiences with these behaviors.

\section{RESEARCH METHODOLOGY}

Data on cyber victims was collected from a variety of secondary sources using a variety of means over several years as part of a larger study on hackers, hacktivists and cyber security issues. Most of the information came from a variety of electronic news sources which were collected each day through the use of Google Search terms. This formed the bulk of the data collected. Media taken from sources other than the internet were also used, such as print newspapers, print magazines, radio and television broadcasts, and documentaries. Each month, the Google Search term feeds were reviewed and binned into appropriate categories. Over time, this amounted to several hundred document sources on several cyberbullying events with thousands of pages of reported information.

In order to condense such a huge amount of information and turn it into a coherent story, the case study method of research was utilized. Yin [31] described two criteria for using this method of study. First, a case study methodology is useful in order to understand a real-life phenomenon in depth, and secondly, a case study handles technically distinctive situations where there are many more variables of interest than data points and multiple sources of evidence. Yin defined three principles of data collection, including using multiple sources of evidence, creating a database of these sources, and maintaining a chain of evidence; all three were adhered to in this present research [31]. Finally, the documents were reviewed for appropriateness, applicability and sorted via their timelines so that they could build the story of the victims' experiences. 
Issues in Information Systems

Volume 15, Issue I, pp. 132-140, 2014

\section{RECENT VICTIMS OF CYBERBULLYING}

\section{Amanda Todd}

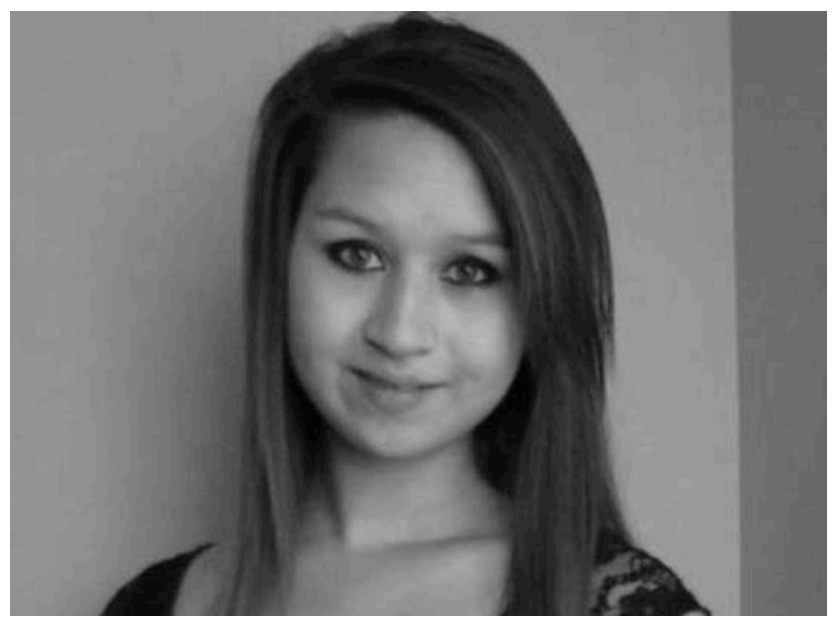

Figure 1. Amanda Todd

Fifteen-year-old Amanda Todd hung herself in her Port Coquitlam, British Columbia, Canada home at 6 p.m. Wednesday, October 10, 2012, one month shy of her $16^{\text {th }}$ birthday, just five weeks after she posted a heartbreaking video on YouTube which detailed how she was harassed and bullied online. The video she posted on YouTube was entitled "My Story: Struggling, bullying, suicide and self harm" [4, 20]. The video, shot in black and white, shows Amanda telling her story on a series of flash cards.

In $7^{\text {th }}$ Grade, in an online video conversation with an unknown man, after being bated with lavish praise telling her how beautiful she was, Amanda was asked to show him her naked breasts; unfortunately, she did. A year later, she was contacted by the man through Facebook. He threatened that if she didn't put on a show for him, he would send the photo to her family, friends and schoolmates. He had somehow obtained all her personal information: Facebook profile, address, school name, names of family members, names of friends, etc. She refused. Over Christmas Break, the police showed up at her door at 4 AM inquiring about the photo of her. Apparently, the photo had been sent out to everyone just as the man had threatened. As a result, she grew depressed and anxious, turning to alcohol and drugs in order to cope with this situation [24].

Amanda ended up switching schools, but the cyberbullying followed her. The man who had threatened her created a Facebook page of her with the picture of Amanda's breasts as his profile picture. Her schoolmates began to make fun of her and picked on her, calling her names. She started cutting herself. She moved to yet another school. She made friends with a boy who told her that he liked her, but he was just leading her on. He had a girlfriend and one day told Amanda that his girlfriend was on vacation and that she should come over to see him. She did and they had sex. A week later, she was confronted by the girlfriend, the boyfriend and a large group of teens in front of her school and beaten up by the girl. The attack was filmed. Amanda's father came to pick her up afterwards and take her home. Despondent, Amanda tried to kill herself by drinking bleach. She was rushed to the hospital and survived [24].

On finding out about her suicide attempt, her Facebook friends posted cruel comments about how she deserved it, did she get the mud out of her hair with the bleach and that they hoped she was dead. She moved in with her mother in a new city and a new school and thought things might get better, but her tormenters followed. Comments on her Facebook page said that she should kill herself and included photos of bleach bottles and ditches which were tagged with her profile. Her anxiety grew to such a level that she rarely left the house; she was prescribed antidepressants and started counseling. After an overdose which required a two day stay in the hospital, she decided to make the video of her experience with bullying [24]. 


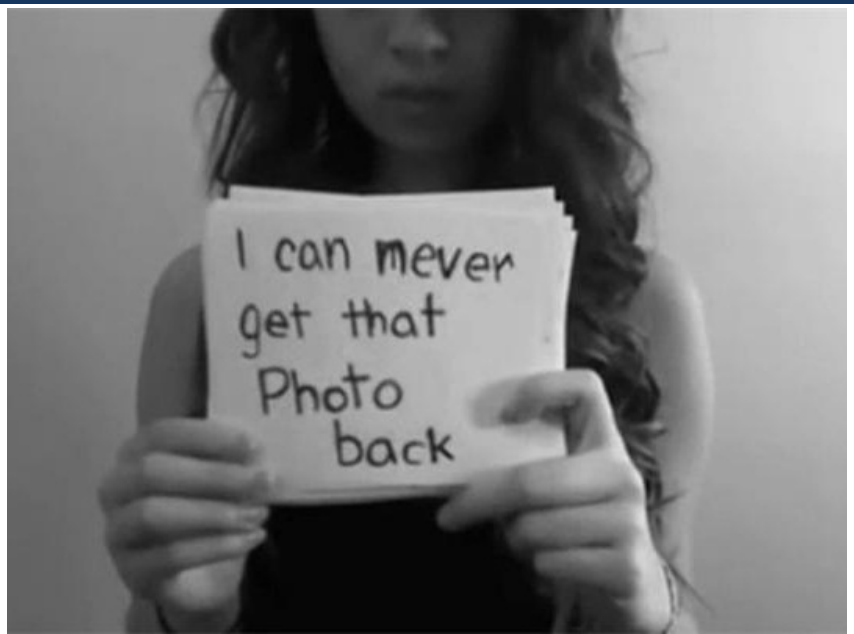

Figure 2. Screenshot from Amanda Todd's YouTube video

The YouTube page includes the following introduction:

I'm struggling to stay in this world, because everything just touches me so deeply. I'm not doing this for attention. I'm doing this to be an inspiration and to show that I can be strong. I did things to myself to make pain go away, because I'd rather hurt myself then [sic] someone else. Haters are haters but please don't hate, although im [sic] sure I'll get them. I hope I can show you guys that everyone has a story, and everyones [sic] future will be bright one day, you just gotta [sic] pull through. I'm still here aren't I? Amanda Todd (2012). [24]

\section{Jessica Laney}

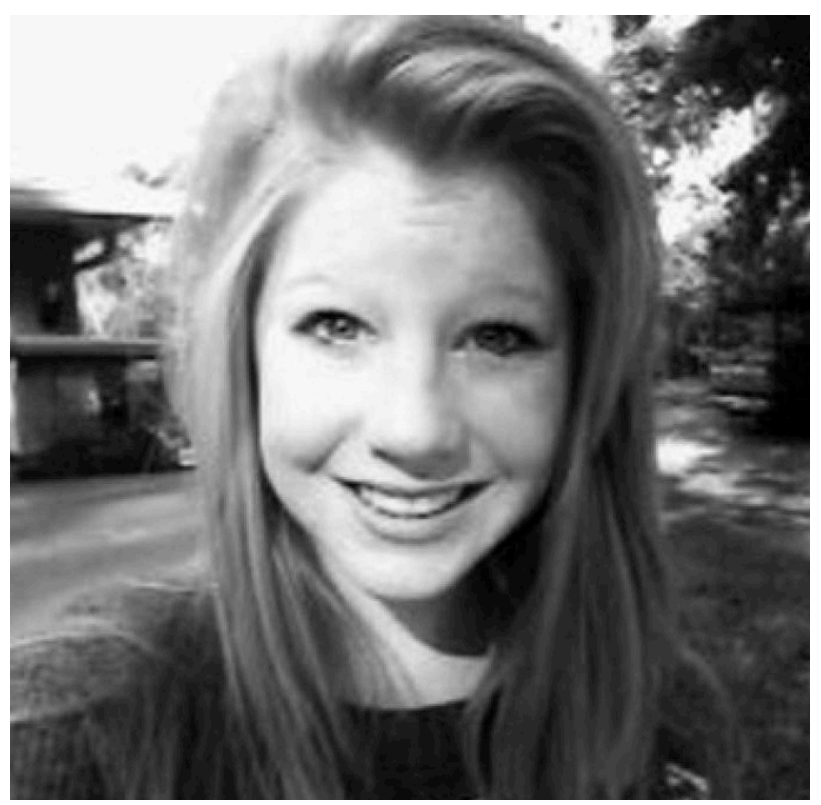

Figure 3. Jessica Laney

On December 9, 2012, a sixteen year old Fivay High School student from Hudson, Florida, Jessica Laney, hung herself. Friends told authorities that she became suicidal after being cyberbullied through the Latvian question and answer website ask.fm [13, 18]. While Laney's ask.fm account page, Jessicamarieee1, had a fair share of innocent comments about what boys in school she liked and telling her how pretty she was, there were also a number of posts disparaging her, telling her she was fat and a loser. 
"Classmates of 16-year-old Jessica Laney say she was pretty and bubbly. Still, cruel comments could be found on her Ask.fm webpage. "Nobody even cares about you," reads one anonymous post. "Can you just kill yourself," says another. Close friends Cheyenne Ellsmore and Lisa Arthur say people would post the mean messages anonymously. "You get compliments sometimes but it's those negative comments that bring you down," Ellsmore said. "There's just things you should say and things you shouldn't," said Arthur. "And on Ask.fm, none of that should be said." The girls believe the comments got to be too much for Laney, who took her own life Sunday night." [11]

Jessica had transferred from Hudson high School to Fivay High School because of bullying there. A friend of Jessica, Valerie Canales, wrote on Jesscia's Facebook tribute page, which was established after her death, that the abuse that she received on ask.fm was what pushed her to take her own life.

"...last night, my friend Jessica Laney took her life. She was constantly bullied and bullied. And she was pushed and pushed to the point where she couldn't handle it anymore. And if you could spread the word about the website ask.fm, \& how it needs to be shut down, that would be amazing too. Ask.fm is a website where people can ask anonymous questions to anyone they want. And thats [sic] how Jessica was constantly put down and bullied. She was a beautiful girl \& everyone loved her. Shes [sic] gonna [sic] be missed. We have to put an end to bullying. Please help..." [18]

\section{Rehtaeh Parsons}

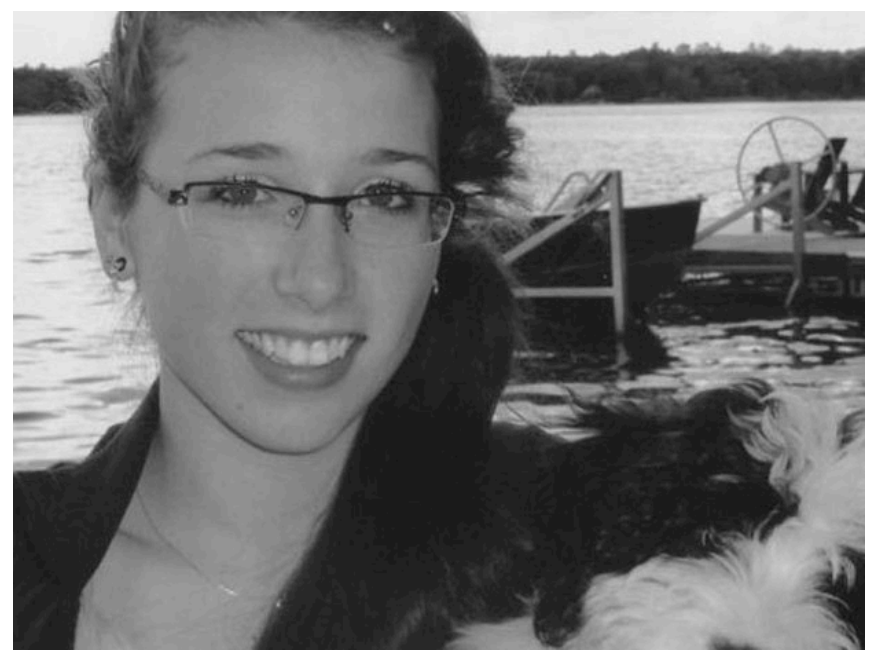

Figure 4. Rehtaeh Parsons

Rehtaeh Parsons, a seventeen-year-old former Cole Harbour District High School student, attempted suicide by hanging on April 4, 2013, at her home in Dartmouth, Nova Scotia, Canada. She did not succeed which led to her falling into a coma. On April 7, 2013, her family made the decision to take her off life support; she died the same day [23]. In November of 2011, Rehtaeh was at a small gathering of friends when she was photographed while having sex with one of the boys. Her mother detailed events of the night on a Facebook memorial page dedicated to Rehtaeh:

The person Rehtaeh once was all changed one dreaded night in November 2011. She went with a friend to another's home. In that home she was raped by four young boys ... one of those boys took a photo of her being raped and decided it would be fun to distribute the photo to everyone in Rehtaeh's school and community where it quickly went viral. Because the boys already had a 'slut' story, the victim of the rape Rehtaeh was considered a slut. This day changed the lives of our family forever. [27]

After that, the bullying and harassment continued unabated. Her mother, Leah Parsons said, "She was never left alone. She had to leave the community. Her friends turned against her. People harassed her. Boys she didn't know 


\section{Issues in Information Systems \\ Volume 15, Issue I, pp. 132-140, 2014}

started texting her and Facebooking her asking her to have sex with them. It just never stopped" [23]. The family moved to nearby Halifax but the cyberbullying did not stop. Rehtaeh began to suffer from depression and anger and at one time had to be admitted to a hospital on fears that she would harm herself. A yearlong investigation by the Royal Canadian Mounted Police (RCMP) concluded that there was not enough evidence to charge and convict any of the boys with rape. After her death, members of the hacker activist group, Anonymous, threatened to release the identity documents or dox of the boys involved unless the RCMP charged them with crimes [28]. However, upon the request of the family, the boys' names and identities were not released by the group [3].

Ultimately, the attention and pressure brought by Anonymous helped to persuade other witnesses to come forward with new information. This convinced the RCMP to reopen the investigation on April 11, 2013 [16]. Finally, in August of 2013, two of the teens involved were arrested and charged with child pornography, not rape. Police commented, "What some people may believe occurred and what can be substantiated in a police investigation through verified evidence and what can finally be proved in court are often very different things. We, as police officers, cannot act on innuendo or speculation. We do not cultivate facts. We verify them" [12].

\section{Rebecca Ann Sedwick}

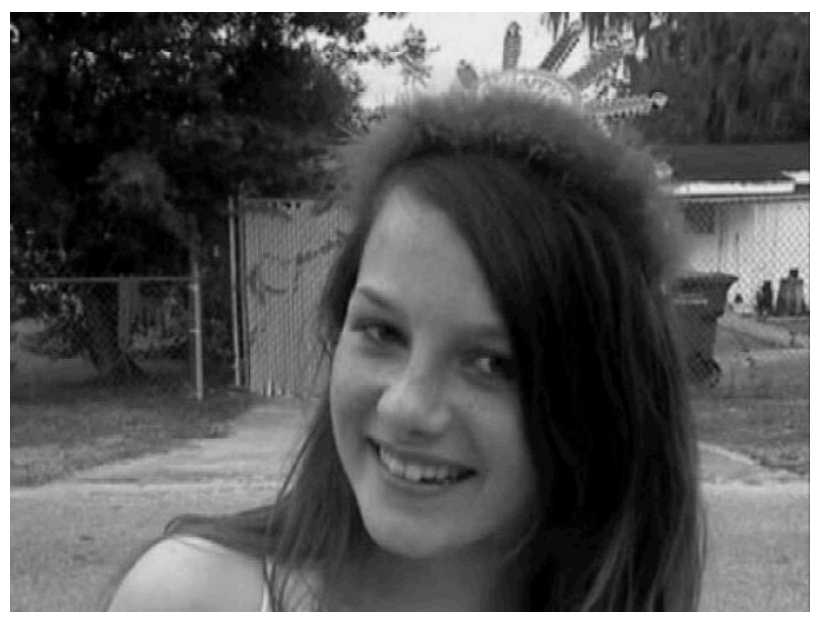

Figure 5. Rebecca Ann Sedwick

On Monday, September 9, 2013, Rebecca Ann Sedwick, a twelve year old Crystal Lake Middle School student, jumped to her death at an old cement business less than one mile from her home in Lakeland, Florida. She had been the victim of cyberbullying for months. Rebecca was reported missing about 7 p.m. Monday by her mother after she failed to return home from school. Authorities later learned she left her home without her books that same morning but never boarded her school bus [22]. After an investigation, two girls were eventually arrested, part of a group of 15 girls who were accused of tormenting Rebecca. The arrests came after one of the two girls tweeted "'Yes IK [I know] I bullied REBECCA nd [sic] she killed her self [sic] but IDGAF [I don't give a fuck]" [17]. The torment began after one of the girls began dating a boy Rebecca had dated earlier and she didn't like that Rebecca and the boy remained friends. She even turned the other girl, formerly a good friend of Rebecca's, against her.

Witnesses told investigators she sent messages to Rebecca, calling her ugly, telling her to "drink bleach and die," and encouraging her to kill herself. Rebecca's computer searches revealed she had searched for ways to commit suicide and asked questions like, "What is overweight for a 13-year-old girl." One of the Florida girl's screensavers also showed Rebecca with her head resting on a railroad track. [Rebecca] changed one of her online screen names to "That Dead Girl." She messaged a boy: "I'm jumping." Polk County Sheriff Judd said Rebecca had been "absolutely terrorized" by the other girls. "We can see from what we've been investigating so far that Rebecca wasn't attacking back," Judd said. "She appeared to be beat down. She appeared to have a defeatist attitude. And quite frankly, the entire investigation is exceptionally disturbing". [17]

Even when her mother took Rebecca out of school, the bullying continued online. In December of 2012, Rebecca was hospitalized for three days after cutting her wrists saying that it was because of bullying. 
"She put on a perfect, happy face. She never told me," [said her mother, Tricia Norman]. "I never had a clue. I mean, she told me last year when she was being bullied, but not this year, and I have no idea why." Once police checked [Rebecca's] cell phone they discovered that the bullying had not stopped, especially on Kik Messenger, Instagram and Ask.fm. "They would tell her she's ugly, stupid, nobody liked her, go kill herself," Ms Norman said. [17]

The two teen girls who were arrested were released but eventually charges were dropped for lack of evidence. However, Rebecca's mother filed wrongful death lawsuits in the civil court. She also began to petition the State of Florida to enact tougher anti-bullying laws [8].

\section{CONCLUSIONS}

While each of these stories is tragic and unique, there are some common threads which can give insight into the recommended steps to help spot warning signs for parents, educators and friends. Bullying and/or cyberbullying had become such common and significant events in all of these girls' lives that parents had to remove them from one school to another, and in the case of Amanda Todd, they even moved out of town. The victims took extreme measures such as self-mutilation and most exhibited signs of depression. Some had been hospitalized after suicide attempts in the past. All of them maintained a presence on the Internet and to varying degrees utilized social media and/or smart phone applications which invited two way communications with anonymous participants. All these events combined paint pictures of vulnerable and fragile teenagers who succumbed to the pain which was in their lives every day. Their social system almost dictated that they maintain an electronic conversation with their peers and that led to the entrance of cyberbullies into their world. In their eyes, the pain and depression became too great to bear and they took the only way out they could think of.

\section{RECOMMENDATIONS}

Just like the proverb that it "takes a whole village to raise a child," it will take "a whole village" to combat cyberbullying. That is, to really prevent and reduce cyberbullying, young people themselves, their parents, their teachers and schools, their community, and society as a whole need to be involved. Parents are encouraged to set rules and talk to their children about technology usage. Not only should parents be aware of what their children are doing online, they should also discuss cyberbullying and encourage their children to talk to them immediately if they are cyberbullied. Teachers should take cyberbullying seriously, be aware of the warning signs, keep open communication with students regarding cyberbullying incidents, and respond to the incident. If young people experience cyberbullying, they should save all information associated with the incident, not respond to the cyberbully, and report the incident. We all must tackle cyberbullying together to have a lasting impact!

\section{REFERENCES}

1. Alvarez, L. (2013, September 13). Girl's suicide points to rise in apps used by cyberbullies. The New York Times. Retrieved from http://www.nytimes.com/2013/09/14/us/suicide-of-girl-after-bullying-raises-worries-onweb-sites.html? $\mathrm{r}=1 \&$

2. boyd, d. (2014). It's Complicated: The Social Lives of Networked Teens. New Haven, CT: Yale University Press.

3. CBC News. (2013, April 12). 'Anonymous' won't release names of Rehtaeh Parsons suspects. Canadian Broadcasting Corporation. Retrieved from http://www.cbc.ca/news/canada/nova-scotia/story/2013/04/12/nsrehtaeh-parsons-anonymous-hackers-names.html

4. Dufour, K. (2012, October 16). Amanda Todd case highlights issue of online bullying. The Telegraph. Retrieved from http://www.telegraph.co.uk/news/worldnews/northamerica/usa/9612030/Amanda-Todd-casehighlights-issue-of-online-bullying.html

5. Espelage, D. \& Horne, A. (2008). School violence and bullying prevention: from research based explanations to empirically based solutions. In Brown, S. \& Lent, R. (Eds.) Handbook of Counseling Psychology, $4^{\text {th }}$ Edition. Hoboken, NJ: John Wiley and Sons.

6. Hinduja, S., \& Patchin, J. W. (2007). Offline consequences of online victimization: School violence and delinquency. Journal of School Violence, 6(3), 89-112. 


\section{Issues in Information Systems \\ Volume 15, Issue I, pp. 132-140, 2014}

7. Katzer, C., Fetchenhauer, D., \& Belschak, F. (2009). Cyberbullying: Who are the victims?: A comparison of victimization in internet chatrooms and victimization in school. Journal of Media Psychology: Theories, Methods, and Applications, 21(1), 25-36.

8. Kemp, J. (2013, November 25). Rebecca Sedwick's mom files suit against teens accused of bullying, pursues tougher laws. New York Daily News. Retrieved from http://www.nydailynews.com/news/national/motherrebecca-sedwick-sues-florida-teens-accused-bullying-article-1.1528226

9. Levy, N, Cortesi, S., Gasser, U., Crowley, E., Beaton, M., Casey, J. and Nolan, C. Bullying in a networked era: a literature review. Kinder \& Braver World Project: Research Series. 2012-17, 1-61. Retrieved from http://ssrn.com/abstract $=2146877$

10. Marwick, A. \& boyd, d. (2011). The drama! Teen conflict, gossip, and bullying in networked publics. $A$ Decade in Internet Time: Symposium on the Dynamics of the Internet and Society, September 2011. Retrieved from http://papers.ssrn.com/sol3/papers.cfm?abstract id=1926349

11. McVey, C. (2012, December 11). Friends blame cyber-bullying for student's suicide. Bay News 9. Retrieved from

http://www.baynews9.com/content/news/baynews9/news/article.html/content/news/articles/bn9/2012/12/11/frie nds blame cyberb.html

12. Morris, K. (2013, August 9). After 2 years, 2 arrests made in Rehtaeh Parsons rape case. The Daily Dot. Retrieved from http://www.dailydot.com/news/rehtaeh-parsons-anonymous-rcmp-arrest-child-pornography/

13. Murray, R. (2012, December 12). Cyber-bullying, social media blamed after Florida teen commits suicide. New York Daily News. Retrieved from http://www.nydailynews.com/news/national/social-media-blamed-teensuicide-article-1.1218550

14. Olweus, D. (1994). Bullying at school: basic facts and effects of a school-based intervention program. Journal of Child Psychology and Psychiatry, 35(7), 1171-1190.

15. Pellegrini, A. (2002). Bullying and victimization in middle school: a dominance relations perspective. Educational Psychologist, 37(3), 151-163.

16. Prentiss, M. (2013, April 16). Rehtaeh Parsons' father thanks Anonymous for help in re-opened case. Global News. Retrieved April 26, 2013 from http://globalnews.ca/news/484351/rehtaeh-parsons-father-thanksanonymous-for-help-in-re-opened-case/

17. Quigley, R \& Gorman, R. (2013, November 21). 'I did nothing wrong': girl, 13, accused of bullying suicide victim Rebecca Sedwick speaks out after charges were dropped. Daily Mail. Retrieved from http://www.dailymail.co.uk/news/article-2511202/Katelyn-Roman-accused-bullying-Rebecca-Sedwick-didwrong.html

18. Roberts, K. (2012, December 11). Jessica Laney suicide: friends say online bullying led to Fivay High School student's death. KPTV. Retrieved from http://www.wptv.com/news/state/jessica-laney-suicide-friends-sayonline-bullying-led-to-fivay-high-school-students-death

19. Schultze-Krumbholz, A \& Scheithauer, H. (2009). Social-behavior correlates of cyberbullying in a German student sample. Journal of Psychology, 217(4), 224-226.

20. Shaw, G. \& Culbert, L. (2012, October 12). Port Coquitlam teen driven to death by cyberbullying (with video). The Vancouver Sun. Retrieved from

http://www.vancouversun.com/technology/Vancouver+area+teen+commits+suicide+after+telling+story+being/ 7375941/story.html

21. Sonawane, V. (2014, March 11). Cyber bullying increases suicidal thoughts and attempts: study. HNGN. Retrieved from http://www.hngn.com/articles/26245/20140311/cyber-bullying-increases-suicidal-thoughtsattempts-study.htm

22. Stennett, D. (2013, September 12). 15 girls identified after cyber-bullied girl jumps to her death in Lakeland. Orlando Sentinel. Retrieved from http://articles.orlandosentinel.com/2013-09-12/news/os-cyber-bullyingsuicide-rebecca-sedwick-20130912_1 judd-school-system-death

23. The Huffington Post. (2013, April 9). Rehtaeh Parsons, Canadian girl, dies after suicide attempt; parents allege she was raped by 4 boys. The Huffington Post. Retrieved from http://www.huffingtonpost.com/2013/04/09/rehtaeh-parsons-girl-dies-suicide-rape-canada n_3045033.html

24. TheSomebodytoknow. (2012, September 7). My story: Struggling, bullying, suicide, self harm [video file]. Retrieved from http://www.youtube.com/watch?feature=player_embedded\&v=vOHXGNx-E7E

25. Tokunaga, R. (2010). Following you home from school: a critical review and synthesis of literature on cyberbullying victimization. Computers in Human Behavior, 26(3), 277-287.

26. Vandebosch, H., \& Van Cleemput, K. (2009). Cyberbullying among youngsters: Profiles of bullies and victims. New Media \& Society, 11(8), 1349-1371. 


\section{Issues in Information Systems \\ Volume 15, Issue I, pp. 132-140, 2014}

27. Visser, J. (2013, April 9). 'The justice system failed her': Nova Scotia teenager commits suicide after being raped, bullied: mother. National Post. Retrieved from http://news.nationalpost.com/2013/04/09/the-justicesystem-failed-her-nova-scotia-teenager-commits-suicide-after-being-raped-bullied-mother/

28. Visser, J. \& Cross, A. (2013, April 10). Anonymous threatens to out boys involved in alleged gang rape of N.S. teen unless RCMP charges them. National Post. Retrieved from http://news.nationalpost.com/2013/04/10/anonymous-threatens-to-out-boys-involved-in-alleged-gang-rape-of-ns-teen-who-committed-suicide-unless-rcmp-charges-them/

29. Wright, M. F., \& Li, Y. (2013). The association between cyber victimization and cyber aggression: The moderating effect of peer rejection. Journal of Youth \& Adolescence, 42(5), 662-674.

30. Ybarra, M. L., \& Mitchell, K. J. (2004). Online aggressor/targets, aggressors, and targets: A comparison of associated youth characteristics, Journal of Child Psychology \& Psychiatry, 45(7), 108-116.

31. Yin, R. (2009). Case Study Research: Designs and Methods, Fourth Edition. Thousand Oaks, CA: Sage 